\title{
PERAN HUMAS SEBAGAI FASILITATOR KOMUNIKASI DALAM MENANGANI KELUHAN PELANGGAN DI PT. PLN DISTRIBUSI JAWA TIMUR
}

\author{
Muchamad Rizqi ${ }^{1}$, Mohammad Insan Romadhan ${ }^{2}$, Devi Kurnia Inayati ${ }^{3}$ \\ Program Studi Ilmu Komunikasi Universitas 17 Agustus 1945 Surabaya \\ Korespondensi: Jalan Semolowaru 45 Surabaya \\ Surel: muchamadrizqi@untag-sby.ac.id
}

\section{INFO ARTIKEL}

Sejarah Artikel:

Diterima: 02/26/20

Direvisi: 20/05/20

Dipublikasikan: 31/05/20

e-ISSN: 2721-0995

p-ISSN: 2721-9046

Kata Kunci:

Public Relations, PT. PLN

Distribusi Jawa Timur,

Asimetris Dua Arah, Miles

dan Huberman

Keywords:

Public Relations, PLN East Java Distribution, Two-way Asymmetric Model, Miles and Huberman

\section{ABSTRAK}

Peran Humas sebagai Fasilitator Komunikasi dalam Menangani Keluhan Pelanggan di PT. PLN Distribusi Jawa Timur. Fasilitator komunikasi merupakan salah satu peran public relations dalam menjembatani antara lembaga dan publiknya. Seperti halnya public relations di PT. PLN Distribusi Jawa Timur yang memiliki peran sangat penting dalam menjembatani komunikasi antara lembaga dengan masyarakat. Sebagai perusahaan yang bergerak dalam jasa penyedia energi, PT. PLN Distribusi Jawa Timur tidak lepas dari berbagai macam kritik dan masukan dari masyarakat terhadap kualitas pelayanannya. Penelitian ini bertujuan untuk menganalisis peran public relations PT. PLN Distribusi Jawa Timur dalam menindaklanjuti keluhan masyarakat dengan menerapkan model asimetris dua arah. Dalam penelitian ini, peneliti menggunakan metode kualitatif dengan pendekatan deskriptif. Pengumpulan data dilakukan melalui wawancara, observasi, dan dokumentasi. Data yang diperoleh dianalisis dengan menggunakan model Miles dan Huberman. Hasil yang ditunjukkan dalam penelitian ini, public relations PT. PLN Distribusi Jawa Timur menggunakan media massa (media cetak dan elektronik) serta media sosial dalam menindaklanjuti keluhan masyarakat.

\footnotetext{
ABSTRACT

The Roles of Public Relations as A Facilitator of Communication in Handling Complaints at PLN East Java Distribution. In PLN East Java Distribution, it is known that the role of Public Relations is a major key in solving the problem of a company or organization given that the PLN East Java Distribution is the provider of electricity for corporate, residential, hotel, and others. This study has the objective to analyze the roles of Public Relations of PLN East Java Distribution in handling customer complaints, by using Public Relations model approach namely two-way asymmetric. This study used a qualitative research method with descriptive approaches: case study, interviews, observation and documentation. Data analysis using Interactive analysis models called Miles and Huberman. The results in this study Public Relations PLN East JavaDistribution bridging communications with customers using multiple media such as printed media, social media, and electronic media in response to customer complaints.
} 


\section{PENDAHULUAN}

Hubungan masyarakat merupakan sebuah kegiatan yang bertujuan untuk menguatkan dan mengubah citra lembaga terhadap publiknya untuk menciptakan sebuah keputusan bersama. Melihat definisi tersebut, maka humas harus memiliki peran dalam membangun komunikasi dua arah. Kepekaan dalam mendengarkan opini publik dan tanggap dalam mengambil tindakan perlu dilakukan untuk mencegah terjadinya kegagalan dalam komunikasi. Komunikasi yang dibangun oleh humas antara lembaga dengan publiknya diharapkan dapat membangun saling pengertian baik tentang penyampaian kebijakan lembaga maupun keinginan dari publik itu sendiri.

Humas sebagai fungsi manajemen bertugas mengevaluasi sikap publik, mengidentifikasi kebijakan dan prosedur baik individual maupun organisasi yang memiliki kepentingan publik. Humas juga merencanakan dan melaksanakan program aksi dalam rangka mendapatkan pemahaman dan penerimaan publik. Dengan demikian, dapat didefinisikan bahwa humas merupakan fungsi manajemen yang membangun dan mempertahankan hubungan baik dan bermanfaat antara organisasi dengan publik yang sangat berpengaruh terhadap kesuksesan atau kegagalan perusahaan tersebut.

Terdapat beberapa elemen utama humas untuk menunjukkan definisi humas itu sendiri, bukan sekadar apa yang dilakukan oleh humas. Akan tetapi, termasuk di dalamnya elemen konseptual dan operasional. Humas adalah fungsi manajemen yang membantu dalam membangun dan mengamankan lini komunikasi, pemahaman bersama, saling menerima, dan kerjasama antara organisasi dan publiknya. Humas melibatkan manajemen krisis dan isu. Humas membantu manajemen agar tetap responsif dan mendapat informasi terkini tentang opini publik, mendefinisikan dan menekankan tanggung jawab manajemen untuk melayani kepentingan publik, membantu manajemen dalam mengikuti perubahan, dan memanfaatkan perubahan secara efektif, serta sebagai sistem peringatan dini untuk mengantisipasi ke mana arah perubahan yang terjadi di dalam masyarakat.

Humas juga berperan dalam membantu lembaga dalam mengatasi krisis dengan memberikan masukan kepada tingkat top management terkait evaluasi kebijakan. Humas memiliki posisi yang sangat vital dalam meningkatkan dan mempertahankan citra positif untuk eksistensi lembaga tersebut. Maka, tidaklah mustahil apabila humas masuk dalam tingkatan top management. Pada prinsipnya keberadaan humas tidak dapat dipisahkan dari suatu struktur organisasi dalam lembaga. Fungsi humas dapat berjalan maksimal apabila memiliki garis koordinasi langsung dengan tingkat top management.

Pemberian saran dalam menanggapi dan menangani suatu kebijakan atau permasalahan perusahaan, fasilitator komunikasi, dan membantu memberikan solusi dalam penyelesaian masalah terkait kebijakan merupakan beberapa peran penting humas dalam sebuah lembaga. Tugasnya tidak hanya menentukan sebuah strategi komunikasi yang memiliki dampak signifikan dalam mewujudkan tujuan dari lembaga, tetapi juga kemampuan dalam menerima informasi dari publik. Faktor yang sangat penting adalah membangun komunikasi dua arah guna memberikan dampak positif bagi lembaga itu 
sendiri. Dalam memberikan pelayanan atau informasi kepada publik, humas sebagai fasilitator komunikasi harus mampu menempatkan lembaga menjadi pendengar yang aktif. $\mathrm{Hal}$ ini harus dilakukan guna menjaga agar komunikasi antara lembaga dengan publiknya tetap berjalan seimbang. Terciptanya komunikasi yang baik antara lembaga dan publik tidak hanya untuk meningkatkan sebuah citra perusahaan tetapi juga untuk pelayanan yang tepat sehingga menjadikan publik merasa nyaman serta percaya untuk tetap menggunakan jasa perusahaan tersebut.

Begitu pula dengan PT. PLN Distribusi Jawa Timur, satu dari sekian banyak perusahaan milik negara yang berorientasi terhadap pelayanan publik harus mampu memberikan pelayanan kepada masyarakat. Sebagai penyediaan jasa layanan untuk masyarakat di Jawa Timur tentunya PT. PLN Distribusi Jawa Timur tidak lepas dari kritik dan saran para pelanggan tentang kepuasan dan kualitas pelayanan. Humas PT. PLN Distribusi Jawa Timur tentunya harus memiliki kemampuan dalam tiga hal utama, yakni reputasi dan citra, jembatan komunikasi, dan menjamin kepada publik bahwa perusahaan berada di dalam operasional yang memiliki niat baik dan bertanggung jawab dalam tugasnya melayani masyarakat.

\section{TINJAUAN PUSTAKA}

\section{Public Relation}

Public Relations merupakan proses strategi komunikasi yang membentuk relasi sehingga ada saling ketergantungan dan saling menguntungkan di antara organisasi dan publiknya. Hal ini merupakan proses yang dapat disebut sebagai proses strategis. Maksudnya ialah public relations memiliki fokus untuk membantu lembaga/organisasi agar tujuan yang diharapkan dapat tercapai secara maksimal. Dengan demikian, public relations memiliki tugas utama untuk membangun komunikasi yang berfokus pada membangun relasi. Semua proses yang dimaksudkan adalah proses yang terencana dengan sasaran memengaruhi opini publik berdasarkan pada komunikasi dua arah dan saling menguntungkan.

Melvin Sharpe (Seitel, 2016:6) menyebutkan bahwa public relations yakni proses menyelaraskan relasi jangka panjang antara individu dan lembaga/organisasi di dalam masyarakat. Proses ini memiliki lima prinsip utama, yaitu: (a) kredibilitas dibangun atas dasar kejujuran dalam berkomunikasi, (b) konsistensi dan keterbukaan sebuah action untuk kepercayaan diri, (c) pengutamaan prinsip keadilan guna mendapatkan hubungan timbal balik dan itikad baik, (d) komunikasi yang bersifat dua arah secara berkelanjutan untuk membangun relasi yang baik, (e) riset dan evaluasi lingkungan guna menentukan langkahlangkah atau ukuran yang diperlukan untuk keharmonisan sosial.

Dalam fungsi manajemen, public relations memiliki posisi strategis untuk berkomunikasi dengan pihak manajemen guna memberikan masukan. Bahkan, pihak manajemen di lini atas dapat mengambil keputusan karena wewenang pengambilan keputusan terkait kebijakan di dalam organisasi ada di tangan manajemen lini atas. Selanjutnya, tugas dari public relations adalah mengomunikasikan keputusan ini secara akurat kepada publiknya. 


\section{Publik dari Public Relations}

Terdapat beberapa kategori publik, yakni:

a. Internal dan eksternal, yakni publik internal merupakan publik yang berada di dalam lingkup internal organisasi dan berhubungan langsung, seperti pekerja, manajer, pemilik saham, dan jajaran manajer sedangkan publik eksternal merupakan publik di luar lingkup organisasi dan tidak memiliki hubungan langsung, seperti media, pemerintahan, konsumen, masyarakat, pemasok, dan sebagainya.

b. Primer dan sekunder, yakni publik primer adalah publik yang memiliki kontribusi yang sangat baik bagi organisasi sedangkan publik sekunder adalah publik yang pengaruhnya tidak terlalu signifikan bagi organisasi.

c. Tradisional, yakni publik yang memiliki pengaruh dan kontribusi yang potensial pada satu waktu yang sama.

d. Masa depan, yakni publik yang memiliki pengaruh dan kontribusi di masa mendatang.

Berdasarkan pengategorian tersebut, publik internal berarti yang harus dihadapi oleh manajer adalah pegawai yang berasal dari berbagai level serta lintas bagian. Publik eksternal berarti yang harus dihadapi oleh manajer adalah sebuah sistem di luar organisasi, seperti pemerintahan, konsumen, organisasi nonpemerintah, dan lain sebagainya. Public relations dalam hal ini dituntut untuk mampu mengatur komunikasi antara organisasi dengan publiknya dengan tetap memperhatikan efektivitas sehingga dapat dikatakan bahwa public relations merupakan mediator antara organisasi dengan publik di antara keduanya samasama memiliki ketergantungan.

\section{Opini Publik}

Vincent Price dan Donald F. Robert (2016:239) menyebutkan bahwa opini publik merupakan pandangan dari individu-individu terhadap isu yang sama. Opini publik mencerminkan sebuah proses dinamis yang di dalamnya terdapat ekspresi dari ide-ide dalam rangka menentukan arah dari suatu tindakan. Opini publik ditemukan di dalam kelompok orang yang memilliki kepentingan dan pandangan yang sama terhadap sebuah isu tentang pandangan, pertanyaan, dan langkah yang akan dilakukan untuk menjadi satu topik kajian dalam sebuah proses komunikasi yang terjadi secara terus menerus.

Effendy (2015:107) menyebutkan bahwa opini publik merupakan efek dari komunikasi yang diwujudkan dalam pernyataan yang sifatnya kontroversial dari beberapa individu. Hal itu diungkapkan sebagai ekspresi terhadap persoalan sosial yang bersinggungan dengan kepentingan masyarakat umum sehingga faktor yang menjadi pengaruh terhadap munculnya opini publik adalah adanya permasalahan yang menyangkut kepentingan bersama. Namun, kondisi berbeda dapat dijumpai di masyarakat yang tidak melihat satu fenomena dari kacamata yang sama.

\section{Model dalam Public Relations}

Terdapat empat model public relations, yakni two-way asymmetric, two-way 
symmentric, press agentry, dan public information. Dalam model-model tersebut terdapat model yang menggunakan pola komunikasi dua arah, yaitu two-way asymmetric dan symmetric. Dalam hal ini humas berperan dalam mengumpulkan informasi dan memberikan balasan informasi kepada publik yang bertujuan untuk pertimbangan bagi manajemen dalam pengambilan keputusan. Walaupun kedua model tersebut memperlihatkan balasan dari publik, dalam model asimetris dua arah lebih mengarah pada strategi komunikasi untuk memberi pengaruh terhadap publik sehingga tetap sesuai dengan ketentuan lembaga, bukan sebaliknya. Perusahaan atau organisasi dipandang masih mengedepankan citranya dibandingkan dengan kepentingan publiknya.

Model asimetris biasanya terjadi pada organisasi yang mempunyai karakeristik seperti yang dipaparkan (Grunig: 1989 dan Grunig \& White 1992) sebagai berikut: (a) berorientasi ke dalam, yaitu anggota organisasi hanya melihat fenomena dari pandangan organisasi itu sendiri dan tidak memandang dari sudut pandang public; (b) cenderung tertutup, yaitu informasi hanya tersebar dari organisasi itu sendiri dan tidak membuka diri pada informasi yang berasal dari luar organisasi; (c) anggapan bahwa efisiensi dan kendali atas segala biaya menjadi prioritas utama daripada kebutuhan inovasi; (d) bersifat elitisme, yaitu keputusan ditentukan hanya oleh pimpinan organisasi; (e) konservatif, yaitu cenderung menolak perubahan; (f) bersifat kewenangan terpusat

Model asimetris dua arah pada model ini terjadi komunikasi dua arah. Namun tidak ada keseimbangan di dalamnya. Informasi dari lembaga sangat dominan. Organisasi berupaya dalam memengaruhi publik dengan pendekatan persuasif yakni publik dituntut untuk menyesuaikan seperti kondisi yang diinginkan oleh organisasi sebagai akibat dari organisasi yang enggan menyesuaikan terhadap apa saja yang menjadi kepentingan publik. Model ini bertujuan untuk memengaruhi dan memanipulasi informasi yang disampaikan kepada publik agar sesuai dengan apa yang diharapkan oleh organisasi melalui beberapa pendekatan, di antaranya tingkah laku, penelitian, dan ilmu sosial. Biasanya, dalam mempersuasi dan memengaruhi publik organisasi mengandalkan pihak ketiga.

\section{METODE}

Pendekatan yang digunakan dalam penelitian ini adalah kualitatif yang mempunyai maksud menjelaskan seluruh peristiwa atau suatu kejadian yang benar adanya tidak dikurangi maupun tidak dilebihkan tetapi apa adanya pada saat penelitian dilakukan oleh peneliti (Kasiram: 2008). Sejalan dengan hal itu, Mulyana $(2001 ; 147)$ menyatakan bahwa metode penelitian kualitatif merupakan pandangan subjektif yang dinamis dan dikonstruksikan dari kebenaran atas realitas yang bersifat relatif. Penelitian ini berjenis deskriptif dengan upaya menggambarkan situasi atau kejadian. Metode dalam penelitian ini menggunakan studi kasus yang mendasarkan pada pengelihatan dalam kehidupan yang sebenar-benarnya. Data primer dan data sekunder bersumber dan didapatkan langsung dari informan. Informan dalam penelitian ini, yaitu Asisten Manajer Komunikasi PT. PLN Distribusi Jawa Timur, Staf CSR, dan Staf Komunikasi PT. PLN Distribusi Jawa Timur. 


\section{HASIL DAN PEMBAHASAN}

Humas merupakan bagian yang sangat vital bagi setiap perusahaan, tidak terkecuali bagi perusahaan milik negara seperti PT. PLN (Persero). Pentingnya posisi humas di dalam sebuah perusahaan tidak dapat dilepaskan dari upaya perusahaan tersebut untuk membentuk dan mempertahankan reputasinya, terlebih untuk meningkatkan kepercayaan masyarakat terhadap eksistensi perusahaan. Pentingnya sebuah reputasi yang berpengaruh langsung terhadap eksistensi perusahaan inilah yang menuntut humas harus dapat menjalin serta memelihara hubungan yang harmonis dengan publiknya.

Sebagai fungsi manajemen, berarti manajemen di semua lembaga/organisasi harus memberikan perhatian lebih terhadap humas. Hal ini juga untuk menganalisis pembentukan dan pemeliharaan hubungan baik dan saling menguntungkan antara lembaga/organisasi dengan publiknya. Selain itu, dikemukakan pula kriteria untuk menentukan bagaimana humas dan apa saja yang bukan termasuk humas. Konsep humas sebagai fungsi manajemen dengan tujuan membangun dan mempertahankan hubungan baik dan bermanfaat antara organisasi dengan publik berpengaruh terhadap eksistensi organisasi tersebut.

Humas PT. PLN Distribusi Jawa Timur memiliki tugas menjamin kualitas pelayanan kepada masyarakat dengan menjaga dan membina hubungan yang harmonis dengan cara mengidentifikasikan segala opini, persepsi, dan tanggapan masyarakat terhadap pelayanan PT. PLN Distribusi Jawa Timur. Humas PT. PLN Distribusi Jawa Timur juga mengevaluasi program-program perusahaan terutama yang menyentuh masyarakat. Komunikasi yang disampaikan oleh humas harus mudah dipahami agar tidak terjadi kesalahan dalam penerimaan pesan yang dapat merugikan perusahaan. Sebagai contoh, kegiatan humas dapat diamati dari interaksi antara Humas PT. PLN Distribusi Jawa Timur dengan para pelanggannya tentang keluhan terhadap pelayanan yang diberikan, terutama saat terjadinya pemadaman listrik yang berdampak hampir di seluruh wilayah Jawa Timur.

Faktor inilah yang menjadikan masyarakat merasa kurang puas dengan layanan PT. PLN Distribusi Jawa Timur. Menanggapi fenomena ini, Humas PT. PLN Distribusi Jawa Timur PLN memiliki peran dalam memberikan informasi-informasi yang bersifat persuasif dengan sejelas-jelasnya sehingga dapat dipahami oleh masyarakat terutama pelanggan. Beberapa cara dilakukan, di antaranya dengan sosialisasi menggunakan media massa konvensional dan media sosial yang tersedia serta turun langsung menemui masyarakat.

Memang tidak semua pelanggan PT. PLN Distribusi Jawa Timur mengalami pemadaman ini, tetapi dampak-dampak akibat pemadaman, seperti menurunnya jumlah produksi barang industri terutama industri rumah tangga berdampak pada penyesuaian harga barang di pasaran. Itulah faktor yang mendorong peran humas sebagai perantara komunikasi perusahaan dalam menjembatani komunikasi secara langsung dengan masyarakat secara tepat dan cepat diperlukan agar reputasi lembaga tetap terjaga dan tidak mengurangi pelayanan yang diberikan kepada masyarakat.

Terdapat dua kunci utama dalam definisi public relations, yakni management dan action. Apabila public relations bekerja untuk menjadi pengayom organisasinya, maka ia 
memiliki tanggung jawab kepada manajemen level atas. Public relations memiliki kewajiban dan dituntut untuk menjadi 'jembatan' yang baik dan jujur bagi pihak manajemen. Yang terpenting public relation mampu bersikap netral untuk menjamin pekerjaan berjalan dengan baik tanpa manipulasi sedikitpun. Tidak ada komunikasi yang dilakukan oleh public relations yang tidak persuasif, mengingat hal inilah yang bisa dijadikan sebagai penyelamat organisasi ketika berada dalam sebuah krisis yang sudah diketahui oleh publiknya.

Humas PT. PLN Distribusi Jawa Timur dalam upaya menyelesaikan dan menangani keluhan masyarakat terkait pelayanan menggunakan pendekatan yang berkarakteristik persuasi dan sistematis. Dalam pengelolaan keluhan pelanggan, PT. PLN Distribusi Jawa Timur tidak secara langsung menangani tetapi melalui tahapantahapan yang sesuai dengan legalitas, yakni dengan aplikasi Contact Center yang meliputi Call Center 123, website, dan juga melalui aplikasi PLN Mobile. Dalam aturan legalnya, PT. PLN Distribusi Jawa Timur juga memiliki layanan pengaduan yang dapat diakses langsung oleh masyarakat dalam waktu 24 jam.

Apabila terdapat keluhan pelanggan yang disampaikan melalui media massa, maka Humas PLN Distribusi Jawa Timur memproses keluhan tersebut dengan memberikan keterangan pers atau dengan memberikan klarifikasi di media yang dimaksudkan. Di sini, Humas PT. PLN Distribusi Jawa Timur membuka pintu kepada masyarakat untuk dapat berkomunikasi atau menyampaikan informasi terkait pelayanan yang diberikan oleh PT. PLN Distribusi Jawa Timur. Informasi yang telah disaring dan dihimpun oleh Humas PT. PLN Distribusi Jawa Timur selanjutnya akan diteruskan kepada kantor cabang atau rayon yang tersebar di seluruh kabupaten/ kota yang dimaksudkan di wilayah Jawa Timur melalui media sosial.

Komunikasi didominasi oleh Humas PT. PLN Distribusi Jawa Timur sesuai dengan konsep model two-way asymmetric. Lane (2005:5) menjelaskan bahwa peran public relations lebih banyak sebagai fasilitator pertukaran informasi antara perusahaan dan publiknya yang bertujuan untuk menguatkan pengaruh perusahaan dan mendorong publik untuk menerima strategi perusahaan sehingga kekuatan dan kontrol hubungan komunikasi masih tetap didominasi oleh perusahaan.

Dalam menjalankan komunikasi dua arah secara langsung, Humas PT. PLN Distribusi Jawa Timur juga terlibat langsung dalam aktivitas sosialisasi dan pemasaran keliling dengan tujuan untuk mengetahui permasalahan di lapangan. Aktivitas tersebut dilakukan dengan cara membuka ruang diskusi langsung dengan masyarakat yang dilakukan di balai desa, balai RW, dan balai pertemuan warga.

Karakteristik penerapan model two-way asymmetric ini adalah komunikasi yang dilakukan dari sumber ke penerima pesan yang menghasilkan feedback. Bagian CSR Humas PT. PLN Distribusi Jawa Timur terlebih dahulu melakukan survei mengenai permasalahan pelanggan dalam skala besar (wilayah tertentu). Kemudian, jika dalam suatu wilayah 
tersebut mengalami kerusakan pada listrik daerahnya yang merugikan banyak pelanggan, maka pihak CSR bekerja sama dengan pihak PLN rayon daerah.

Tahapan akhir dalam menyelesaikan permasalahan guna menghasilkan hal yang diinginkan adalah proses evaluasi. Dalam menyelesaikannya, Humas PT. PLN Distribusi Jawa Timur bekerja sama dengan media massa guna memberi informasi terkait keluhan pelanggan dan kebijakan-kebijakan perusahaan agar terhindar dari pemberitaan yang tidak benar. Adanya aktivitas lapangan yang dilakukan langsung oleh Humas PT. PLN Distribusi Jawa Timur juga dapat dilakukan untuk mengetahui kondisi sebenarnya yang ada di lapangan terkait permasalahan yang dialami masyarakat.

\section{SIMPULAN}

HumasPT.PLN Distribusi Jawa Timurberperan sebagaifasilitatorkomunikasi, yaitu sebagai jembatan komunikasi masyarakat yang kemudian disampaikan kepada pihak PLN rayon daerah yang tersebar di Jawa Timur agar penanganan keluhan dapat segera ditindaklanjuti sesuai dengan wilayah kerja PT. PLN Distribusi Jawa Timur. Dalam menjembatani komunikasi dengan masyarakat, Humas PT. PLN Distribusi Jawa Timur menggunakan media massa dan media sosial. Humas PT. PLN Distribusi Jawa Timur melakukan komunikasi dua arah dengan pelanggan baik secara langsung maupun tidak langsung. Dalam berkomunikasi dengan konsumen secara tidak langsung, Humas PT. PLN Distribusi Jawa Timur menggunakan media yang kemudian disampaikan ke bagian pengaduan pelayanan pelanggan sesuai dengan aturan legal yang berlaku, sedangkan secara langsung dilakukan melalui aktivitas sosialisasi dan pemasaran keliling yang menghasilkan umpan balik dari masyarakat.

\section{DAFTAR RUJUKAN}

Butterick, Keith. 2012. Pengantar Public Relations: Teori dan Praktik. Jakarta: Rajawali Pers.

Bernie, Mohammad. (2018). Derita Korban Denda PLN: Percuma Melawan Pelanggan Tak Akan

Menang. https://tirto.id//derita-korban-pln-percuma-melawan-pelanggan-tak-akanmenang-cHHz. Akses 20 September 2018 pukul 14.00 WIB

Creswell W, John. 2014. Penelitian Kualitatif \& Desain Riset. Jakarta: Pustaka Belajar

Cutlip, Scott M, Center, Allen H, Broom, Glen M. 2016. Effective Public Relations, edisi kesembilan. Jakarta: Prenadamedia.

Diahloka, Carmia. (2011). Strategi Humas (Public Relations) dalam Menangani Komplain Pelanggan pada Pelayanan Produk (Studi pada Plasa Telkom Malang). Jurnal Ilmiah Ilmu Sosial dan Ilmu Politik Universitas Tribhuana Tunggaldewi Malang, 1 (1), 1-10.

Ishaq El, Ropingi. 2017. Public Relations: Teori \& Praktik. Malang: Intranas Publishing Ismoyo, Bay. (2018). Dampak Pemadaman Listrik PLN: Dari Gangguan Kereta Sampai Pembayaran Tol. http://www.bbc.com/indonesia/amp/trensosial-42540533. Akses 20 Juli 2019 pukul 17.00 WIB

Jawa Pos. (2019). Mahasiswa Kembali Gelar Aksi Tuntut PLN. Tersedia secara daring di tautan http://www.jawapos.com/jpg-today/03/04/2019/mahasiswa-kembali-gelar-aksi-tuntutpln/\%3famp. Akses 20 Juli 2019 pukul 18.00 WIB

Kadafi, Mohammad. (2018). Ini Penyebab Listrik Bali dan Sebagian Jawa Timur Padam Total. http//www.google.com/amp/s/m.merdeka.com/amp/uang/ini-penyebab-listrik-bali-dansebagian-jawa-timur-padam-total.hmtl. Akses 19 September 2018 pukul 13.00 WIB 
Kusumastuti, Frida. 2004. Dasar-Dasar Hubungan Masyarakat. Bogor Selatan: Penerbit Ghalia Indonesia

Larasati, Belinda Devi. (2016). Peran Humas Pemerintah sebagai Fasilitator Komunikasi pada Biro Humas Pemprov Kalimantan Selatan Strategi Humas (Public Relations). Jurnal Penelitian Komunikasi, 19 (1), 55-58.

Londa, J. W. (2014). Peran Petugas Humas Sebagai Komunikator Pembangunan (Studi di Bagian Humas Kantor Pemerintahan Kabupaten Minahasa Selatan). Jurnal Acta Diurna, 3 (2), 12-21.

Romadhan, M. I., Rohimah, A. \& Pradana, B. C. S. A. (2019). Implementation of Public Relations Model in Sosializing Local Culture to Sumenep's Young Generation. Jurnal MetaKom, 3 (2), 97-108.

Ruslan, Rosady. 2003. Metode Penelitian: Public Relation dan Komunikasi. Jakarta: PT. Raja Grafindo Persada.

Ruslan, Rosady. 2010. Manajemen Public Relations dan Media Komunikasi. Jakarta: PT. Rajawali Pers.

Seitel, Fraser P. 2016. Praktik Public Relations, edisi keduabelas. Jakarta: Erlangga.

Soemirat, Soleh, Ardianto, Elvinaro. 2015. Dasar-Dasar Public Relations. Bandung: Rosdakarya.

Suryabrata, Sumandi. 2018. Metodologi Penelitian. Depok: Rajawali Pers.

Yusuf A, Muri. 2014. Metode Penelitian: Kuantitatif, Kualitatif, dan Penelitian Gabungan. Jakarta: Fajar Interpratama Mandiri. 